\title{
Grazing rates on bacteria by marine heterotrophic microflagellates compared to uptake rates of bacterial-sized monodisperse fluorescent latex beads
}

\author{
Kari Nygaard*, Knut Yngve Børsheim**, T. Frede Thingstad \\ Department of Microbiology and Plant Physiology, University of Bergen, Allégt 70, N-5007 Bergen, Norway
}

\begin{abstract}
Uptake rates of monodisperse fluorescent latex beads by heterotrophic microflagellates were investigated under controlled laboratory conditions and in Masfjorden, S Norway. In 2-stage continuous cultures it was shown that for a Bodo sp., ingestion of latex beads was considerably less efficient than ingestion of bacteria. The selection coefficient (clearance rate of beads/clearance rate of bacteria) decreased with increasing dilution rate, implying that slow-growing or starving microflagellates discriminated less efficiently against latex beads. Only between 17 and $50 \%$ of the flagellates grown at different dilution rates contained latex beads after incubation for 20 mirn, whereas $80 \%$ were found to ingest FITC-stained bacteria. In a comparison among 8 species of bacterivorous microflagellates, one species did not take up beads at all, while the other species ingested beads to a variable extent. In seawater samples from Masforden, the number of organisms found to take up beads was, as a mean, only $60 \%(n=6)$ of the number found to take up FITC-stained bacteria. Results imply that if latex beads are used to measure grazing rates on bacteria, corrections for selectivity are required to avoid serious underestimates. With selectivity being growth-rate-dependent such corrections may be complicated. The use of stained bacteria as markers seems more promising.
\end{abstract}

\section{INTRODUCTION}

Bacterivorous microflagellates are currently believed to harvest a major portion of bacterial production in aquatic environments (Fenchel 1982a, b, c, d, Azam et al. 1983, Sherr \& Sherr 1983), and furthermore the magnitude of bacterial production may be a larger percentage of total primary production than postulated in earlier literature (Moriarty 1987). This relatively new conception has inspired researchers to give marine protozoa fresh attention (Andersen \& Fenchel 1985, Andersen \& Sørensen 1986, Andersson et al. 1986, McManus \& Fuhrman 1986, Wikner et al. 1986). However, only a limited number of methods of quantifying the biomass of marine heterotrophic flagellates are available, and methods for studying their physiological state or activity in nature have been sparse or non-

\footnotetext{
- Present address: Institute of Marine Research, Austevoll Marine Aquaculture Station, N-5392 Storebe, Norway

- Addressee for correspondence
}

existent. To measure grazing by individual flagellates on bacteria, the use of fluorescent bacterial-sized artificial particles as tracers has been suggested (Cynar \& Sieburth 1986, McManus \& Fuhrman 1986). Børsheim (1984) introduced this approach to quantify grazing by ciliates on bacteria, and later used it to measure grazing and size selection by various suspension feeders (Børsheim \& Andersen 1987, Johnsen \& Børsheim in press). Pace \& Bailiff (1987) have recently shown that this method gives an unbiased estimate of the grazing rate on bacteria by certain ciliates. However, they also found that the method may yield underestimates of grazing rates when applied to microflagellates.

Here we report results from experiments designed to test whether bacterivorous flagellates discriminated against latex particles as compared to bacteria, whether the ability to discriminate was dependent upon grazing rate, and whether it differed among species. We also discuss the use of fluorescent latex beads to measure grazing rates on bacteria in field experiments. 


\section{MATERIALS AND METHODS}

Continuous culture. In a 2-stage continuous culture,

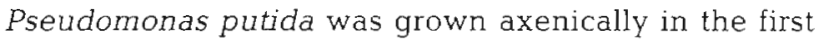
stage at constant dilution rate. The effluent from the axenic culture was fed to a second growth chamber which had been inoculated with a bacterivorous flagellate. The flagellate was a Bodo sp., denoted Bodo sp. I. The culture chambers had equal volumes so the dilution rates were equal for both stages.

Aeration and stirring of the cultures were provided by bubbling with sterile, moistened air, combined with a magnetic stirrer. Temperature was kept constant at $15^{\circ} \mathrm{C}$. The bacterial medium was based on the marine algae medium described by Guillard \& Ryther (1962), with an addition of $0.25 \mathrm{mM}$ glucose. The bacteria were glucose limited (Pengerud et al. 1987). The glucose concentration was measured with a commercial peroxidase reagent ('Glox', KabiVitrum).

The clearance rate of bacteria in the mixed culture was calculated as:

$$
C R=\left[\left(N_{b 1}-N_{b 2}\right) / N_{f}\right] \times D
$$

where $N_{\mathrm{b} 1}=$ number of bacteria in Stage $1 ; N_{\mathrm{b} 2}=$ number of bacteria in Stage $2 ; N_{\mathrm{f}}=$ number of flagellates in Stage 2; $D=$ dilution rate

Uptake rates of latex beads. Monodisperse latex beads, size $0.57 \mu \mathrm{m}$, prestained with yellow-green fluorescence, were purchased from Polysciences Inc., Warrington, Pennsylvania, USA. Previous tests have shown that latex beads of this size aggregate very rapidly when suspended in seawater. This problem was solved by immobilizing protein on the latex surfaces. The beads were suspended in bovine serum albumin solution $(6 \%)$ for $12 \mathrm{~h}$, and washed after centrifugation to remove surplus protein. Any remaining aggregates of beads were removed by filtering through a $1.0 \mu \mathrm{m}$ Nuclepore filter.

To measure uptake rates in flagellate cultures, beads were added to $100 \mathrm{ml}$ of culture, to a concentration of $10 \%$ of the bacterial concentration, which was measured using DAPI as described below. Uptake rates were computed from the first, linear part of a curve based on subsamples taken after incubation for $20 \mathrm{~min}$, $1 \mathrm{~h}$ and $2 \mathrm{~h}$. In natural samples, $250 \mathrm{ml}$ was incubated for $1 \mathrm{~h}$ with beads at a concentration of 10 to $50 \%$ of the total count of bacteria.

Number of flagellates and number of beads in each flagellate cell were counted with epifluorescence and phase contrast microscopy as described below.

Clearance rates were calculated as:

$$
C R=B_{\text {ind }} /(C \cdot t)
$$

where $B_{\text {ind }}=$ number of beads per flagellate; $C=$ concentration of beads during the incubation; $t=$ incubation time.
FITC-stained bacteria. An axenic culture of Vibrio natriegens was stained for $10 \mathrm{~min}$ with $1 \%$ FITC (fluorescein isothiocyanate) solution. The cells were washed with autoclaved, $0.2 \mu \mathrm{m}$ filtered seawater after centrifugation, and this treatment was repeated 3 times. The resuspended bacteria were sonicated for $1 \mathrm{~min}$, filtered through $3 \mu \mathrm{m}$ pore-size Nuclepore filters to remove aggregates of bacteria, and stored frozen. Before use the suspensions were examined for bacterial aggregates using the microscope. For measurement of uptake, the flagellate cultures were incubated with stained bacteria following the same protocol as for fluorescent latex beads. Precise enumeration of FITCstained bacteria in vacuoles was difficult due to rapid bleaching under the microscope, and flagellates were only classified as to whether bacteria had been ingested or not.

Species variation in bead uptake. Two different Bodo spp. were isolated from Sorfjorden, north of Bergen, Norway. One was enriched by inoculating $10 \mathrm{ml}$ of seawater to the second stage of a continuous culture system, with a dilution rate of $0.1 \mathrm{~h}^{-1}$, for $1 \mathrm{wk}$. The second was enriched in a batch culture. Both cultures were made axenic by series of dilution. These cultures are named Bodo sp. I and Bodo sp. II respectively. Bodo sp. III was isolated from the Barents Sea by serial transfers on cultures of $p_{\text {seudomonas putida. }}$ Paraphysomonas sp., Bodo parvulus, Pseudobodo sp., Pteridomonas danica and Diaphanoeca sp. were isolated and identified by Professor Tom Fenchel, University of Aarhus, Denmark.

The flagellates were grown on pure cultures of bacteria on a shaking table at $10^{\circ} \mathrm{C}$ and beads were added to the mixed cultures to $10 \%$ of the bacterial concentration when the flagellate number reached approximately $5 \times 10^{4}$ cells $\mathrm{ml}^{-1}$. Uptake was determined by epifluorescence microscopy of live specimens.

Field investigations. Uptake of beads and FITCstained bacteria was measured over a 1 yr cycle in Masfjorden, Southern Norway. Masfjorden is a landlocked marine basin, approximately $300 \mathrm{~m}$ deep, with a shallower inlet about $80 \mathrm{~m}$ deep.

Samples from the euphotic layers were taken with a Ruttner sampler. Values are given as means for 8 depths within the photic zone: only minor variances were found between depths.

Grazing measurement by fractionated filtration. On one occasion, community grazing of bacterivores was measured in Masfjorden using the fractionated filtra. tion method described by Wright \& Coffin (1984). Replicate samples from $5 \mathrm{~m}$ were incubated in situ with and without prefiltration through 1 um pore-size Nuclepore filters. The bacterial concentration was measured at different time intervals using DAPI as described above. 
Microscopic enumeration. Samples were preserved with $\mathrm{HgCl}_{2}$, final concentration $11 \mathrm{mM}$, and filtered on polycarbonate filters of either $0.2 \mu \mathrm{m}$ (bacteria), or 1.0 $\mu \mathrm{m}$ (eucaryotes) pore-size, prestained with Irgalan black (Hobbie et al. 1977). Suction was kept in the range 0.01 to 0.03 bar.

The bacteria were stained with DAPI (diamidinophenylindole) (Porter \& Feig 1980).

Samples for microscopy of protozoa were subsequently stained with primuline (Caron 1983) and DAPI (Porter \& Feig 1980). With primuline staining the autofluorescence of chlorophyll could be used to distinguish between heterotrophic and autotrophic flagellates in field samples. If, however, primuline is used as the only stain, small, poorly preserved flagellates may be confused with detrital particles. The additional staining with DAPI allows detection of the presence of a nucleus and thereby a confirmation of the identification of a flagellate.

For measurement of uptake of FITC-stained bacteria or fluorescent beads, Nuclepore filters with a pore size of $1 \mu \mathrm{m}$ were pretreated in a $10 \%$ Tween 80 solution overnight to reduce adsorption of beads/bacteria to the filter. Aliquots from the incubations were filtered onto the shiny side of these filters, and the collected material was transferred to microscope slides using the quantitative freezing technique (FTF) described by Hewes et al. (1984).

Bacteria and protozoa were counted in a standard Zeiss microscope with a $50 \mathrm{~W}$ HBO mercury lamp, $63 \times$ plan-Neofluar objective and Kpl-W $10 \times$ oculars. FrTCstained bacteria and fluorescent beads were observed using the Zeiss 487709 filter set and DAPI-stained bacteria and protozoa were observed using the Zeiss 487702 filter set.

The biovolume of bacteria and flagellates was estimated from measurements of linear dimensions and simple geometric models as described by Børsheim \& Bratbak (1987).

\section{RESULTS}

Bacteria-sized latex beads tend to aggregate rapidly when dispersed in seawater. It was found that this could be prevented by pretreating the beads with Tween 80, pyrophosphate, or bovine serum albumin. We chose to treat the beads with protein because we felt that this might produce the surface which would be the least alien to the grazer.

Preliminary tests measuring uptake rate of beads by enrichments of flagellates, showed that the sedimentation chamber as described by Børsheim (1984) gave high background that made counting of the ingested beads difficult. Likewise, samples collected and inspected on filters were very difficult to count. The beads tended to stick to the filter, and the shapes of the organisms were frequently distorted beyond recognition in these preparations. Most of these problems were solved by using the FTF technique to remove the filter. With untreated 1 um Nuclepore filters it was found that the $0.57 \mu \mathrm{m}$ beads were concentrated during filtration. This problem was greatly reduced by treating the filters with a $10 \%$ solution of Tween 80 before use.

\section{Continuous culture}

The bacterial concentration in the stabilized continuous cultures was $2 \times 10^{5} \mathrm{ml}^{-1}$ in the first stage, and $7 \times 10^{6} \mathrm{ml}^{-1}$ in the second stage. Both cell numbers of bacteria and growth yield of flagellates were constant at the dilution rates tested. The size of the bacterial cells was approximately $0.9 \times 0.5 \mu \mathrm{m}$ in all the cultures. The growth yield of the flagellates calculated as volume flagellates produced per volume bacteria consumed was $10 \%$.

The glucose concentration in the first growth chamber in the continuous culture stabilized below the detection level of the measurements. Therefore, clearance rate of the bacteria by the flagellate was calculated assuming that no growth of bacteria occurred in the second growth chamber. If this assumption is incorrect, predation rates, and thereby also selection coefficients, have been underestimated.

From the incubations with $0.57 \mu \mathrm{m}$ latex beads it was found that the flagellates showed an increased ability to discriminate between bacteria and beads with increasing growth rate (Table 1).

The ability to take up latex beads was also compared to the uptake of FITC-stained bacteria, using similar incubation and microscopy procedures. It was found that the fraction of flagellates that ingested bacteria

Table 1. Bodo sp. Clearance rates on bacteria in the continuous cultures at different dilution rates, compared to coefficient of selection against latex beads. Clearance rates on bacteria were calculated from dilution rate, number of flagellates in the second stage, and the decrease in bacterial numbers between the first and second stage. Clearance rates on beads were measured in subsamples incubated with $0.57 \mu \mathrm{m}$ beads

\begin{tabular}{|cccc|}
\hline $\begin{array}{c}\text { Dilution rate } \\
\left(\mathrm{h}^{-1}\right)\end{array}$ & $\begin{array}{c}\text { Clearance rates } \\
\left(\mathrm{nl} \text { ind } \mathrm{i}^{-1} \mathrm{~h}^{-1}\right)\end{array}$ & Selectivity \\
Bacteria & Beads & \\
\hline 0.02 & 1.1 & 0.61 & 0.55 \\
0.04 & 2.2 & 0.79 & 0.36 \\
0.05 & 2.8 & 0.90 & 0.32 \\
0.09 & 5.0 & 0.90 & 0.18 \\
\hline
\end{tabular}


was fairly constant, and that the percentage of flagellate cells that ingested beads was persistently lower and decreased with increasing dilution rate (Table 2). It was not possible to count individual bacteria within the flagellates after ingestion, so this technique could not be used to measure uptake rates.

\section{Variation among species}

The ability to discriminate between latex beads and bacteria was examined for 8 different species of bacterivorous microflagellates. The cultures investigated showed varying uptake, and one of the species did not ingest beads at all (Table 3 ).

\section{Field results}

In samples from Masfjorden, it was found that the number of heterotrophic flagellates that ingested FITCstained bacteria was always higher than the number that ingested latex beads. On average, the ratio was $0.60(\mathrm{SD}=0.22, n=6$; Table 4$)$

The clearance rates on latex beads for each sampling date are shown in Table 5. As expected, highest uptake rates were observed during the summer. The winter values were one order of magnitude lower than the value recorded in June. Clearance rates computed as multiples of flagellate cell volumes cleared $\mathrm{h}^{-1}$ (Table 5) were in the range $1.9 \times 10^{4}$ to $5.0 \times 10^{5}$. This may be compared to the range $5.2 \times 10^{4}$ to $1.1 \times 10^{6}$ reported by Fenchel (1982b) as maximum clearance rates in an investigation of 6 different species.

The growth of bacteria in samples incubated with and without prefiltration through $1 \mu \mathrm{m}$ pore size filters was measured on 7 May 1986. In the filtered sample, bacterial biomass increased linearly for $2 \mathrm{~d}$, presumably because of reduced or totally removed grazing pressure (Fig. 1). In the unfiltered sample, little change was detectable for almost $2 \mathrm{~d}$, followed by a sudden burst of bacterial growth. Grazing rate as calculated from the difference between the filtered and unfiltered sample in the 0 to $40 \mathrm{~h}$ period of the experiment was $10.1 \mathrm{nl}_{\mu l^{-1}} \mathrm{~h}^{-1}$.

\section{DISCUSSION}

Measuring grazing by direct microscopy of ingested particles provides an opportunity to measure activity rates of single individuals of the plankton. The uptake rate may serve as an indicator of the physiological state of the bacterivorous flagellates present in field samples. Thus the quantitative importance of the species present, or of higher taxa, can be evaluated.

McManus \& Fuhrman (1986) suggested that latex particle mixtures sold for use as the basis of paint may be a suitable tracer of bacterivory. Such particles are a mixture of sizes and shapes and they argued that this tracer will better mimic the diversity of the natural bacterial community. However, as Cynar \& Sieburth (1986) pointed out, the size distribution of paint particle mixtures may be quite different from the size distribution of the bacteria. Using the method of McManus \& Fuhrman (1986), each investigator has to process his

Table 2. Percentage of microflagellatge cells observed with ingested monodisperse fluorescent beads or FITC-stained bacteria after incubation experiments of samples from continuous cultures at different dilution rates

\begin{tabular}{|ccc|}
\hline $\begin{array}{c}\text { Dilution rate } \\
\left(\mathrm{h}^{-1}\right)\end{array}$ & $\begin{array}{c}\text { \% microflagellates with uptake } \\
\text { Of FITC-stained bacteria }\end{array}$ & Of beads \\
\hline 0.02 & 80 & 50 \\
0.04 & 86 & 37 \\
0.05 & 78 & 30 \\
0.09 & 81 & 17 \\
\hline
\end{tabular}

Table 3. Comparison among 8 species of bacterivorous microflagellates of their ability to ingest $0.57 \mu \mathrm{m}$ latex beads. The Bodo spp. were grown on Vibrio natriegens, the other species were grown on Pseudomonas putida

\begin{tabular}{|c|c|c|}
\hline \multirow[t]{2}{*}{ Flagellate species } & \multicolumn{2}{|c|}{$\%$ microflagellates with uptake } \\
\hline & After $24 \mathrm{~h}$ & After $48 \mathrm{~h}$ \\
\hline Paraphysomonas sp. & 18 & 38 \\
\hline Pteridomonas danica & 18 & 40 \\
\hline Diaphanoeca sp. & 25 & 40 \\
\hline Pseudobodo sp. & 21 & 43 \\
\hline Bodo parvulus & 15 & 41 \\
\hline Bodo sp. I & 15 & 39 \\
\hline Bodo sp. II & 20 & 45 \\
\hline Bodo sp. Ill & 0 & 0 \\
\hline
\end{tabular}

Table 4. Percentage of heterotrophic microflagellates containing FITC-stained bacteria or $0.57 \mu \mathrm{m}$ fluorescent latex beads after incubation of field samples from Masfjorden

\begin{tabular}{|cccc|}
\hline Date & $\begin{array}{c}\text { \% heterotrophic flagellates } \\
\text { with uptake } \\
\text { Of bacteria }\end{array}$ & Ratio \\
\hline 25 Jun 1985 & ND beads & \\
6 Nov 1985 & 8 & 28 & ND \\
30 Jan 1986 & 3 & 5 & 0.63 \\
12 Mar 1986 & 7 & 2 & 0.67 \\
10 Apr 1986 & 24 & 10 & 0.86 \\
7 May 1986 & 18 & 5 & 0.42 \\
17 Jun 1986 & 39 & 29 & 0.74 \\
ND: not determined & & \\
\hline
\end{tabular}


Table 5. Average uptake rates of $0.57 \mu \mathrm{m}$ latex beads by heterotrophic microflagellates in field samples from Masfjorden, compared to average cell volume

\begin{tabular}{|cccc|}
\hline Date & $\begin{array}{c}\text { Average } \\
\text { cell volume } \\
\left(\mu \mathrm{m}^{3}\right)\end{array}$ & $\begin{array}{c}\text { Clearance } \\
\text { rate } \\
\left.\text { (nl ind. }{ }^{-1} \mathrm{~h}^{-1}\right)\end{array}$ & $\begin{array}{c}\text { Specific clear- } \\
\text { ance rate } \\
(\mathrm{nl} \text { [nl body } \\
\left.\text { volume] }{ }^{-1} \mathrm{~h}^{-1}\right)\end{array}$ \\
\hline 25 Jun 1985 & 14.0 & 7.0 & $5.0 \times 10^{5}$ \\
6 Nov 1985 & 18.2 & 0.4 & $2.2 \times 10^{4}$ \\
30 Jan 1986 & 39.5 & 0.75 & $1.9 \times 10^{4}$ \\
12 Mar 1986 & 33.3 & 1.0 & $3.0 \times 10^{4}$ \\
10 Apr 1986 & 46.2 & 6.0 & $1.3 \times 10^{5}$ \\
7 May 1986 & 11.0 & 1.0 & $9.1 \times 10^{4}$ \\
17 Jun 1986 & 51.8 & 5.7 & $1.1 \times 10^{5}$ \\
\hline
\end{tabular}

own batches of tracers. If such undefined tracers are used, it may become a problem to compare results from different laboratories. With monodisperse particles on the other hand, clearance rates on defined sizes can be measured through the size range of natural bacteria.

Sherr et al. (1987) have developed a technique using fluorescently stained bacteria that can be counted after ingestion in flagellates. We found that when using common stains such as acridine orange or DAPI, the stain spread to the whole cell of the bacterivore immediately after ingestion, so that single cells within the food vacuoles could not be counted. Sherr et al. (1987) solved this problem by staining bacteria with DTAF (5-[4:6-dichlorotriazin-2-yl]-aminofluorescein) under elevated temperatures. Spread of the stain was not a problem with FITC-treated bacteria, but the fluorochrome bleached rapidly when exposed to UVlight. This problem may possibly be avoided by using a suitable antioxidant. The idea of using stained bacteria as tracers of grazing is attractive, but monodisperse latex particles may be more suitable in some investigations. They are simple to obtain and handle, and they are available in a variety of monodisperse sizes throughout the size range of natural bacteria. In investigations of size selection, the use of latex beads may therefore be the preferred approach (Fenchel 1980, Børsheim \& Andersen 1987).

Size selection can also be determined by measuring changes in size distribution of the prey related to grazing (e.g. Andersson et al. 1986). However, pure or nearpure cultures of the predator will then be needed, and such cultures are not available for all important bacterivores.

The uptake rates of monodisperse latex beads found by Cynar \& Sieburth (1986) were low compared to other published values of grazing rates on bacteria. Reviewing the literature, they concluded that selectivity by bacterivorous flagellates against latex beads was not to be expected from the information available. Our results from the continuous cultures demonstrated that the bead uptake rate underestimates the uptake rate of bacteria. On average, uptake rates of beads were $35 \%$ of the grazing rate on bacteria. Also, only $33 \%$ of the cells took up beads, whereas $81 \%$ took up FITCstained bacteria. We also found that when the flagellates were given a limiting food supply, their ability to sclect against latex beads decreased. The bacteria in these cultures were of similar size, so this was not an effect of size selectivity. If our results indi-

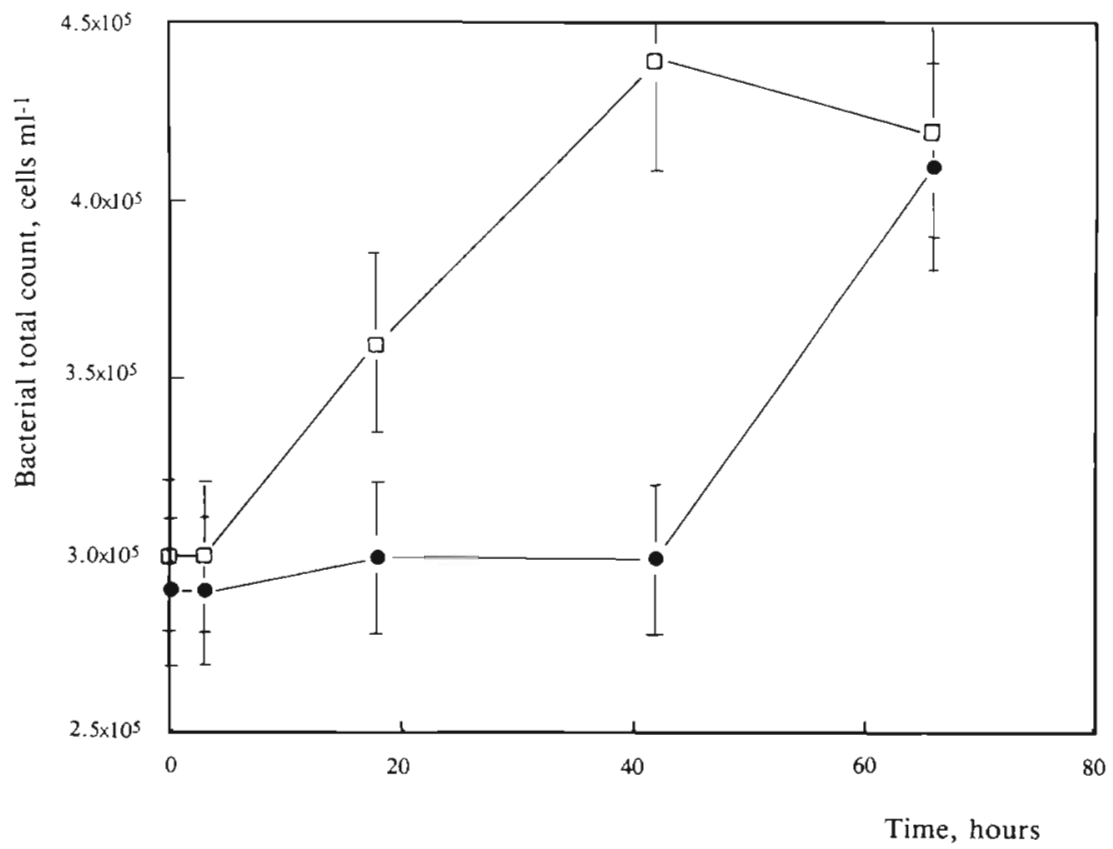

Fig. 1. Bacterial total number in samples from Masfjorden incubated in situ after (a) filtration through $1 \mu \mathrm{m}$ pore size filters and ( $\bullet$ ) without pretreatment. Error bars indicate difference between replicates 
cating that selectivity changes with ingestion rate are generally valid, this introduces the complication of a correction factor which is dependent upon the value to be measured.

When using the latex bead method to detect and count bacterivores in nature, the existence of bacterivorous species with the ability to completely avoid ingestion of such particles obviously becomes a problem. Such species were also found by Pace \& Bailiff (1987). These authors tested selectivity by ciliates, and found that the ciliates tested did not select against beads, whereas the flagellates did. It seems that selection by flagellates may be a general phenomenon. Since flagellates ingest bacteria in much smaller quantities than ciliates, they may have the time and ability to evaluate each food particle. Any attempt to use the bead uptake method to obtain realistic estimates of clearance rate of bacteria in the field would thus have to correct for a selectivity that is apparently dependent both on species composition and on predation rate.

Other methods have been suggested that provide estimates of total grazing pressure on the bacterial community (Landry \& Hassett 1982, Fuhrman \& McManus 1984, Wright \& Coffin 1984, Wikner et al. 1986). Those methods are in general not suitable for investigating what taxonomic groups are active harvesters of the bacteria. The total grazing pressure on bacteria by the community of bacterivores can be calculated from the bead uptake experiments by summing the grazing activity of the species detected. This would produce minimum estimates because the transferring and freezing technique can hardly be expected to preserve all organisms always, creating another potential source for underestimation of grazing rate.

The effect of using the results from the continuous cultures to correct field results was tested in the comparison with fractionated filtration. Three basic undocumented assumptions must be made: (1) the clearance rate on bacteria by the flagellates in the field samples is underestimated by a factor of 0.35 (the average selectivity in the continuous culture experiments); (2) the corrected clearance rate on beads by the cells can be used as an unbiased estimate of the average clearance rate by all the active bacterivorous flagellates; (3) the fraction of active bacterivores is determined by the FITC method. In the sample from May 1986 uptake rates of beads was $1 \mathrm{nl} \mathrm{cell}{ }^{-1} \mathrm{~h}^{-1}$, and the ratio between numbers of cells that took up latex beads and FITC-stained bacteria was 0.3 . There were 4. heterotrophic flagellate cells $\mu l^{-1}$, and from this and the assumptions defined above the total community

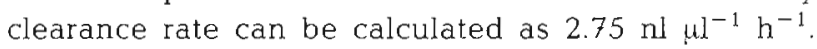
From the fractionated filtration growth experiment the total grazing on bacteria was found to be $10.1 \mathrm{nl} \mathrm{ll}^{-1}$ $\mathrm{h}^{-1}$. Thus, grazing by flagellates as estimated from the corrected bead method was $27 \%$ of the total grazing rate estimated by the Wright \& Coffin (1984) method. The discrepancy may be caused by grazing from other groups of bacterivores such as ciliates, or species that are poorly detected by the FTF technique that we used to prepare the microscope slides. Also, it is possible that the filtration procedure underestimates the true grazing by heterotrophic flagellates, because grazers may squeeze through the filter and survive (Fuhrman \& McManus 1984, Cynar \& Sieburth 1986).

Because there are uncertainties about the validity of both methods, further tests are needed to conclude whether this reflects a real difference between flagellate grazing and grazing on bacteria by other groups.

We do not know how the flagellates distinguish between a bacterium and a latex bead. They have approximately similar size, but have different shape and different surface properties. We doubt that the flagellates avoid the beads because they are spherical, because there is no evidence that cocci are enriched in heavily grazed environments (pers. obs.). Selection is probably based on chemosensory evaluation of the surface macromolecules or even surface charge, or on detection of typical bacterial surface protuberances such as pili or flagellae. Rassoulzadegan et al. (1984) found that marine suspension-feeding larvae accepted latex beads more easily when the beads had been treated with used algal media. It may be worthwhile to look for alternative treatments of the latex beads to increase their acceptability by the flagellates. Also such experiments could give information on the nature of the selectivity.

All our results indicate that serious underestimations of grazing rates by flagellates on bacteria may result using the presently available versions of the latex bead method, and that the use of correction factors may be complicated. Despite this, however, the pattern of changes observed in the field investigations conforms to expectations with high values in summer compared to winter. As an indicator of relative activities, the method may therefore be of value even in its present version.

Acknowledgements. This investigation was supported by The Royal Norwegian Council for Scientific and Industrial Research, grant HB.30.18707, and by 'Masfjordenprosjektet' which is a joint project of the Institute of Marine Research and the University of Bergen.

\section{LITERATURE CITED}

Andersen, A., Larsson, U., Hagström, Å. (1986). Size-selective grazing by a microflagellate on pelagic bacteria. Mar Ecol. Prog. Ser. 33: 51-57 
Andersen, P., Fenchel, T (1985). Bacterivory by microheterotrophic flagellates in seawater samples. Limnol. Oceanogr. 30: $198-202$

Andersen, P., Sorensen, H. M. (1986). Population dynamics and trophic coupling in pelagic microorganisms in eutrophic coastal waters. mar. Ecol. Prog. Ser. 33; 99-109

Andersson, A., Larsson, U., Hagström, $\AA$. (1986). Size-selective gazing by a microflagellate on pelagic bacteria. Mar. Ecol. Prog. Ser. 33: 51-57

Azam, F., Fenchel, T., Field, J. G., Gray, J. S., Meyer-Reil, L. A., Thingstad, T F. (1983). The ecological role of watercolumn microbes in the sea. Mar. Ecol. Prog. Ser. 10: $257-263$

Børsheim, K. Y. (1984). Clearance rates of bacteria-sized particles by freshwater ciliates, measured with monodisperse fluorescent latex beads. Oecologia (Berl.) 63: 286-288

Børsheim, K. Y., Andersen, S. (1987). Grazing and food size selection by crustacean zooplankton compared to production of bacteria and phytoplankton in a shallow Norwegian mountain lake. J. Plankton Res. 9: 367-379

Børsheim, K. Y., Bratbak, G. (1987). Cell volume to cell carbon conversion factors for a bacterivorous Monas sp. enriched from seawater. Mar. Ecol. Prog. Ser. 36: 171-175

Caron, D. A. (1983). Technique for enumeration of heterotrophic and phototrophic nanoplankton, using epifluorescence microscopy, and comparison with other procedures. Appl. environ. Microbiol. 46: 491-498

Cynar, F. J., Sieburth, J. McN. (1986). The unambiguous detection and improved quantification of phagotrophy in apochlorotic nanoflagellates using fluorescent microspheres and concomitant phase contrast and epifluorescence microscopy. Mar. Ecol. Prog. Ser. 32: 61-70

Fenchel, T (1980). Suspension feeding in ciliated protozoa: functional response and particle selection. Microb. Ecol. 6: $1-11$

Fenchel, T (1982a). Ecology of heterotrophic microflagellates. I. Some important forms. Mar Frol Prog Ser. 8: 211-223

Fenchel, T. (1982b). Ecology of heterotrophic microflagellates. II. Bioenergetics and growth. Mar. Ecol. Prog. Ser. 8: 225-231

Fenchel, T (1982c). Ecology of heterotrophic microflagellates. III. Adaptions to heterogeneous environments. Mar. Ecol. Prog. Ser 9: 25-33

Fenchel, T. (1982d). Ecology of heterotrophic microflagellates. IV. Quantitative occurrence and importance as bacterial consumers. Mar. Ecol. Prog. Ser 9: 35-41

Fuhrman, J. A., McManus, G. B. (1984). Do bacterial sized marine eucaryotes consume significant bacterial production? Science 224: 1257-1260
Guillard, R. R. L., Ryther, J. H. (1962). Studies of marine diatoms. I. Cyclotella nana Hustedt and Detonula confervacea (Cleve) Gran. Can. J. Microbiol. 8: 229-239

Hewes, C. D., Reid, F. M. H., Holm-Hansen, O. (1984). The quantitative analysis of nanoplankton: a study of methods. J. Plankton Res. 6: 601-613

Hobbie, J. E., Daley, R. J., Jasper, S. (1977). Use of nuclepore filters for counting bacteria by fluorescent microscopy. Appl. environ. Microbiol. 33: 1225-1228

Johnsen, G. H., Børsheim, K. Y (in press). Bosmina longispina functional response and food size selection. J. Plankton Res.

Landry, M. R., Hassett, R. P. (1982). Estimating the grazing impact of marine micro-zooplankton. Mar. Biol. 67: $283-288$

McManus, G. B., Fuhrman, J. A. (1986). Bacterivory in seawater studied with the use of inert fluorescent particles. Limnol. Oceanogr. 31: 420-426

Moriarty, D. J. W. (1987). Measurement of bacterial growth rates in aquatic systems from rates of nucleic acid synthesis. In: Marshall, K. C. (ed.) Advances in microbial ecology VI. Plenum Press, New York, p. 245-291

Pace, M. L., Bailiff, M. D. (1987). An evaluation of the fluorescent microsphere technique for measuring grazing rates of phagotrophic organisms. Mar. Ecol. Prog. Ser. 40: 185-193

Pengerud, B., Skjoldal, E. F., Thingstad, T F. (1987). The reciprocal interaction between degradation of glucose and ecosystem structure. Studies in mixed chemostat cultures of marine bacteria, algae, and bacterivorous nanoflagellates. Mar Ecol. Prog. Ser. 35: 111-117

Porter, K., Feig, Y S. (1980). The use of DAPI for identifying and counting aquatic microflora. Limnol. Oceanogr. 25: $943-948$

Rassoulzadegan, F., Fenaux, L., Strathmann, R. R. (1984). Effect of flavour and size on selection of food by suspension-feeding plutei. Limnol. Oceanogr 29: 357-361

Sherr, B. F., Sherr, E. B. (1983). Enumeration of heterotrophic microzooplankton by fluorescence microscopy. Estuar. coast. Shelf Sci. 16: 1-7

Sherr, B. F., Sherr, E. B., Fallon, R. D. (1987). Use of monodispersed, fluorescently labeled bacteria to estimate in situ protozoan bacterivory. Appl. environ. Microbiol. 53: 958-965

Wikner, J., Andersen, A., Normark, S., Hagström, $\AA$. (1986). Use of genetically marked minicells as a probe in measurement of predation on bacteria in aquatic environments. Appl. environ. Microbiol. 52: 4-8

Wright, R. T., Coffin, R. B. (1984). Measuring microzooplankton grazing on marine bacteria by its impact on bacterial production. Microb. Ecol. 10: 137-149

This article was presented by Professor J. S. Gray; it was accepted for printing on February 16, 1988 